\title{
Removal of Organic Micropollutants from Riverine Waters using Constructed Wetlands: A Mesocosms Experiment
}

\author{
José J. Palacin Salcedo1, German H. Enamorado Montes², Amado E. Navarro Frómeta ${ }^{3 *}$, \\ Aracelly Caselles Osorio ${ }^{1}$, José Marrugo Negrete ${ }^{2}$ \\ ${ }^{1}$ Universidad del Atlántico, Colombia. \\ ${ }^{2}$ Universidad de Córdoba, Grupo de Aguas Química Aplicada y Ambiental, Colombia. \\ ${ }^{3}$ Universidad Tecnológica de Izúcar de Matamoros, Prolongación Reforma 168, barrio de Santiago Mihuacán, \\ Izúcar de Matamoros, Puebla, México, C.P. 74420.
}

\begin{abstract}
Constructed wetlands (CWs) are a viable technology that can remove organic micropollutants (OMPs) through synergic processes that involve interactions between vegetation biomass and microorganisms, such as hydrolysis, volatilization, sorption, biodegradation, and photolysis. This is accomplished through a combination of design conditions of the wetlands, such as the hydraulic retention times, type of particulate material, and type of selected plant. In this study, the elimination of alkylphenols (AFs), atrazine (ATZ), methyl dihydrojasmonate (MDHJ), caffeine (CAF), and galaxolide (GAL) in horizontal sub-surface flow CWs was evaluated in a pilot system consisting of eight mesocosms with surface areas of $0.6 \mathrm{~m}^{2}$. Four of them were filled with river gravel and the other four were filled with volcanic gravel (tezontle). Six of the systems were planted with Typha latifolia (Ty), Cyperus papyrus (Cyp), and Phragmites australis (Phr) in each of the support mediums, and two of the wetlands remained without plants and were used as control cases. The systems were fed with synthetic river water, in which the concentrations of AFs, ATZ, MDHJ, CAF, and GAL were similar to those historically and currently found in the Nexapa river (Mexico), and the hydraulic retention times (HRT) of 1, 3 and 5 days were used. The results of this study allow to conclude that planted horizontal sub-surface flow CWs can eliminate OMPs from riverine waters with efficiencies (OMP, plant, HRT) between 54 (AFs, Cyp, 1day) and 98\% (CAF,.Typ, 5 days).
\end{abstract}

Keywords: organic micropollutants, constructed wetlands, removal efficiency.

\section{INTRODUCTION}

Organic micropollutants (OMPs) are of great interest in environmental studies worldwide due to their continuous occurrence and persistence in aquatic media [1]. OMPs, also known as emerging contaminants, are a large group of anthropogenic substances found in pharmaceuticals, personal care products, steroid hormones, industrial chemical substances, pesticides, herbicides. Due to their hydrophilic nature, their incorporation into aquatic media always occurs, making their elimination in conventional urban wastewater treatment systems difficult [2] by remaining at relatively stable concentrations, which classifies them as pseudo persistent and producing unknown toxicological damage. The primary effects are related to the reduced diversity of macroinvertebrates in rivers and compartmental changes in fish populations; additionally, there are several detrimental effects on humans [3].

Although OMPs compounds have been detected in surface waters at low concentrations (ranging from ng $\mathrm{L}^{-1}$ to $\mu \mathrm{g} \mathrm{L}^{-1}$ ), these compounds can have endocrine disrupting, chronic toxic and lethal effects on aquatic organisms and up in the trophic chain [4]. The technologies that are most widely used to eliminate these types of contaminants are ozonation, inverse osmosis, and advanced oxidation processes that, although efficient, are expensive [5]. On the contrary, the use of natural systems, such as constructed wetlands (CWs), is increasingly becoming a viable alternative to eliminate this type of pollutant in surface waters [6-8]. Horizontal sub-surface flow (HSSF) CWs consist of impervious surface beds, which are filled with granular material and planted with aquatic macrophytes through which wastewater flows without contacting the atmosphere [9]. Their primary advantages are their low operation and maintenance costs and their high efficiency in eliminating traditional pollutants from wastewater [10]. However, currently, there is a lack of knowledge on how to eliminate OMPs in these systems [11]. The diversity of the physicochemical properties of these compounds and their great complexity in the physical (adsorption by granular medium), chemical (precipitation), and biological (biodegradation through microorganisms and absorption by plants) processes that occur in these systems allow for wastewaters containing OMPs to be treated [11]. However, more information is still required on how to eliminate these pollutants to understand the plant-substratemicroorganism relationships as natural purification processes. These pollutants are becoming increasingly more common in surface waters and wastewaters [12]. Even though there is a general consensus among many researchers on the potential of CWs technologies to eliminate a wide range of organic compounds, the current knowledge on the elimination efficiency of emerging contaminants is still limited, including the knowledge of the elimination mechanisms involved and the effect of certain parameters, such as the design, temperature, seasons, $\mathrm{pH}$, oxygen, oxidation-reduction potential, etc, [13]. Diordo and Carvalho [12] highlighted the influence of a support medium in eliminating organic xenobiotics in CWs, and Zhang et al. [14] reported the importance of photodegradation and biodegradation in eliminating certain drugs. 
To evaluate the implementation of CWs as a viable technology to mitigate the impact of the elevated pollution that exists in the Nexapa river basin [15], which is a tropical dry zone with temperature variations between 20 and $35^{\circ} \mathrm{C}$ during the day and night, a HSSF CW experiment was designed to determine the effect of aquatic macrophytes, Phragmites australis (Phr), Typha latifolia (Ty), and Cyperus papyrus (Cyp), on eliminating emerging contaminants, such as alkylphenols (AFs), atrazine (ATZ), methyl dihydrojasmonate $(\mathrm{MDHJ})$, caffeine (CAF) and galaxolide (GAL). Different experimental conditions were used to determine the elimination efficiency of these pollutants and their relationship with the macrophyte species planted, the hydraulic retention times (HRT), and the type of substrate used.

\section{MATERIALS AND METHODS}

\subsection{Setup and implementation of the experiments}

The experiment was carried out for six months in the facilities at the Universidad Tecnológica de Izúcar de Matamoros (UTIM) in Puebla, Mexico. An experimental HSSF CW treatment system was installed and evaluated, which consisted of eight $0.60 \mathrm{~m}^{2}$ plastic containers distributed in parallel, as shown in Figure 1. The plastic containers simulated a trapezoidal geometry with the following dimensions: a base (B) of $0.96 \mathrm{~m}$, a base (b) of $0.5 \mathrm{~m}$, and a height of $0.33 \mathrm{~m}$. Four of the eight containers were filled with volcanic gravel (tezontle - TZ) and four (4) were filled with river gravel (G), as porous medium (PM) with 4 - and $10-\mathrm{mm}$ average particle sizes respectively. The water level in the systems was maintained at $0.25 \mathrm{~m}$.

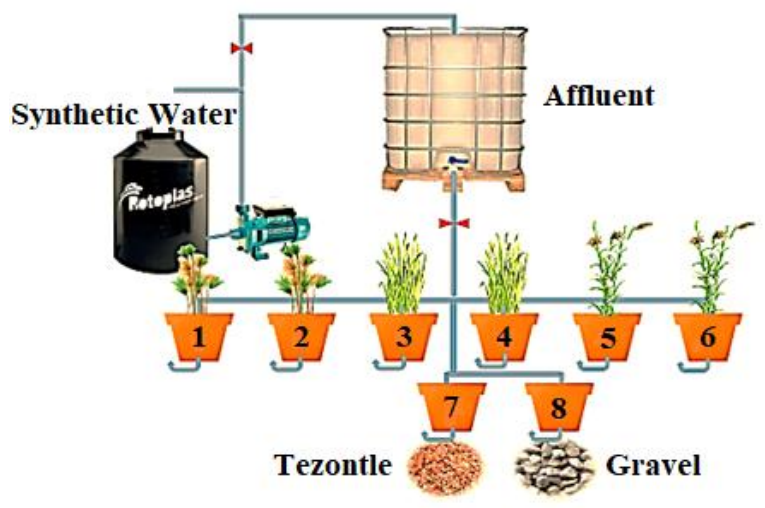

Figure 1. Experimental horizontal sub surface flow constructed wetlands

Affluent water containing AFs, ATZ, MDHJ, CAF and GAL, nutrients and organic matter were poured into the mesocosms from the $1-\mathrm{m}^{3}$ capacity container via gravity using a 1.5 -inch PVC pipe. The systems were fed daily at flow rates of 12.7 , 21.8 , and $42.4 \mathrm{~mL} \mathrm{~min}^{-1}$ to maintain hydraulic retention times (HRT) of 5, 3, and 1 day respectively.

The macrophytes Phr, Ty, and Cyp were obtained from areas near the Nexapa river and transported to the UTIM laboratories for acclimatization. After two months of adaptation and when the plants acquired a height of $0.40 \mathrm{~m}$, they were planted in six of the eight (8) wetlands positioned in parallel at a density of 24 plants per wetland. The two remaining wetlands were unplanted and used as control cases in the experiment.

\subsection{Synthetic water composition and sampling campaigns}

The synthetic river water was prepared according to the characteristics of the water of the Nexapa river [15]. Thus, a mixture was formulated with the proportions of the organic matter, AFs, ATZ, MDHJ, CAF, and GAL recorded in the river. A total of $100 \mathrm{~g}$ of glucose $\mathrm{C}_{6} \mathrm{H}_{12} \mathrm{O}_{6}, 120 \mathrm{~g}$ of $\left(\mathrm{NH}_{4}\right)_{2} \mathrm{SO}_{4}, 9 \mathrm{~g}$ of $\mathrm{KH}_{2} \mathrm{PO}_{4}, 11 \mathrm{~g}$ of $\mathrm{K}_{2} \mathrm{HPO}_{4}$, and $19 \mathrm{~g}$ of $\mathrm{FeCl}_{3} \cdot 6 \mathrm{H}_{2} \mathrm{O}$ were added to $1 \mathrm{~m}^{3}$ of tap water. The synthetic river water concentrations of ammonia nitrogen $\left(\mathrm{N}_{-} \mathrm{NH}_{4}{ }^{+}\right)$, nitrate nitrogen $\left(\mathrm{N}_{-} \mathrm{NO}_{3}{ }^{-}\right)$, orthophosphates $\left(\mathrm{P}-\mathrm{PO}_{4}{ }^{3-}\right)$, biological oxygen demand $\mathrm{BOD}_{5}$, AFs, ATZ, MDHJ, CAF, $\mathrm{GAL}, \mathrm{pH}$, electrical conductivity and turbidity are shown in table 1 .

Table 1. Physicochemical characteristics of the synthetic river water prepared for the mesocosms experiments

\begin{tabular}{|c|c|c|c|}
\hline Parameter & Mean & Parameter & Mean \\
\hline $\mathrm{pH}$ & 7.85 & $\mathrm{DBO}_{5}\left(\mathrm{mg} \mathrm{L}^{-1}\right)$ & 102.6 \\
\hline Turbidity (UNT) & 11.28 & AFs $\left(\mu \mathrm{g} \mathrm{L}^{-1}\right)$ & 3.6 \\
\hline Electrical conductivity $\left(\mu \mathrm{S} \mathrm{cm}^{-1}\right)$ & 2166 & $\operatorname{ATZ}\left(\mu \mathrm{g} \mathrm{L}^{-1}\right)$ & 39.25 \\
\hline $\mathrm{N}-\mathrm{NH}_{4}^{+}\left(\mathrm{mg} \mathrm{L}^{-1}\right)$ & 17.56 & $\operatorname{MDHJ}\left(\mu \mathrm{g} \mathrm{L}^{-1}\right)$ & 4.84 \\
\hline $\mathrm{N}^{-\mathrm{NO}_{3}}{ }^{-}\left(\mathrm{mg} \mathrm{L}^{-1}\right)$ & 13.38 & $\mathrm{CAF}\left(\mu \mathrm{g} \mathrm{L}^{-1}\right)$ & 14.9 \\
\hline 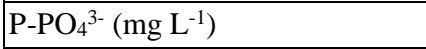 & 21.25 & GAL $\left(\mu \mathrm{g} \mathrm{L}^{-1}\right)$ & 2.68 \\
\hline
\end{tabular}

The systems were fed daily with synthetic river water, where the entry and exit flow rates were controlled. Flow rate values in all systems were used to calculate evapotranspiration, as the difference between the water quantity entering and exiting the systems. As the concentrations of AFs, ATZ, MDHJ, CAF, and GAL were expressed in $\mu \mathrm{g} \mathrm{L}^{-1}$, the removal efficiencies were calculated based on the surface loads of the emerging contaminants expressed in $\mu \mathrm{g} \mathrm{m}^{-2} \mathrm{~d}^{-1}$. Two series of sampling campaigns were carried out each of 5 samplings for each HRT. The experiments were performed sequentially for the different HRT, with a sufficient interval between each one to avoid the overlapping of removal effects. In each sampling, a liter of water was taken for the determinations of OMPs.

\subsection{Chemical analysis}

AFs, ATZ, MDHJ, CAF, and GAL analysis involved filtering the samples, solid phase extraction of the liquid phase [16], and by an ultrasound-assisted extraction of the particulate phase of the water samples [17], followed by a clean-up through a chromatographic column [18]. The samples were previously spiked with a mixture of surrogates to evaluate recoveries. The GC/MS analysis of the combined extracts was performed in a Clarus SQ 680 gas chromatographer coupled with a Clarus SQ 8 T gas spectrometer (Perkin Elmer), with an AB5-MS capillary column of $30 \mathrm{~m} \times 0.25 \mathrm{~mm}$ ID and phase thickness of $0.25 \mu \mathrm{m}$. The temperature program had an initial 
temperature of $90^{\circ} \mathrm{C}$, a $5 \%$ min ramp to $290^{\circ} \mathrm{C}$, and an isothermal regime that lasted $30 \mathrm{~min}$. Ultra-high purity helium was used as a carrier gas $\left(1.5 \mathrm{~mL} \mathrm{~min}^{-1}\right)$. One microliter of each of the samples was injected using a $2: 1 \mathrm{v} / \mathrm{v}$ proportion of trimethylsulfonium hydroxide as in situ derivatizing agent. The quantitation of AFs, ATZ, MDHJ, CAF, and GAL was done using six-point calibration curves $(\mathrm{R}>0.999)$. For quality assurance, extraction blanks and fortified samples were analyzed through all the experimental period.

\subsection{Statistical Analysis}

The measured concentrations of AFs, ATZ, MDHJ, CAF and GAL in affluent and effluent water were related to the measured flow rates entering and exiting each wetland to establish the surface load applied to the experimental systems. To determine the influence of the plants, HRT, and substrates, a factorial ANOVA was performed after assessing the data normality and the homogeneity of the variances. Significant differences were calculated based on each combination of treatments using a Tukey range test at a significance level of $p$ 0.05. All statistical analyses were performed using STATISTICA 13 software (TIBCO Software Inc).

\section{RESULTS}

The average influent and effluent organic loads of AFs, ATZ, MDHJ, CAF, and GAL are shown in table 2, mean influent loads were $200.78 \pm 116.92$, $47.41 \pm 31.76$, $298.43 \pm 184.61$, $889.90 \pm 496.61$ and $132.45 \pm 71.22 \mu \mathrm{g} \mathrm{m}^{-2} \mathrm{~d}^{-1}$ respectively.

The mean overall removal of micropollutants were 79.00, 56.11, 70.26, 95.07 and $79.86 \%$ for AFs, ATZ, MDHJ, CAF, and GAL, respectively. The removal percentages presented in table 3 showed the highest values for ATZ with $98.35 \%$ in the TZ mesocosm planted with Ty at 5 days of HRT, and the lowest value $21.62 \%$ for GAL in G unplanted system at 1 day of HRT

The ANOVA results (Table 4, figures 2-4) show that removal efficiency of CAF and GAL were influenced by plants type and hydraulic retention time; AFs and ATZ removal influenced by plants type, hydraulic retention time and their interaction; MDHJ removal are affected by porous medium, plant type and hydraulic retention time, and the porous medium and plant interaction. Figure 2 exemplifies that for most of the studied compounds the systems planted with Ty showed the highest removals. As was expected the removals percentages increase from 1 to 5 days of HRT as shown in figure 3 for the case of AFs as an example. Figure 4 shows the interaction between the effect of porous medium and plants in the removal of MDHJ.

Table 2. Average organic loads $\left(\mu \mathrm{g} \mathrm{m}^{-2} \mathrm{~d}^{-1}\right)$ of AFs, ATZ, MDHJ, CAF and GAL of the experiments as a function of treatment.

\begin{tabular}{|c|c|c|c|c|c|c|c|}
\hline \multicolumn{3}{|l|}{ Experiment } & \multirow{2}{*}{$\begin{array}{l}\text { AFs } \\
286.44 \pm 101.05\end{array}$} & \multirow{2}{*}{$\begin{array}{l}\text { ATZ } \\
71.56 \pm 25.36\end{array}$} & \multirow{2}{*}{$\begin{array}{l}\text { MDHJ } \\
447.62 \pm 179.43\end{array}$} & \multirow{2}{*}{$\begin{array}{l}\text { CAF } \\
1428.37 \pm 417.20\end{array}$} & \multirow{2}{*}{$\begin{array}{l}\text { GAL } \\
166.69 \pm 46.57\end{array}$} \\
\hline Affluent/HRT & & 1 & & & & & \\
\hline & & 3 & $178.04 \pm 101.70$ & $27.84 \pm 13.40$ & $223.47 \pm 101.72$ & $769.67 \pm 194.26$ & $158.15 \pm 110.12$ \\
\hline & & 5 & $137.06 \pm 88.97$ & $40.86 \pm 36.78$ & $175.23 \pm 92.53$ & $482.08 \pm 138.78$ & $102.73 \pm 69.58$ \\
\hline \multirow[t]{6}{*}{ Effluent Phr } & G & 1 & $71.48 \pm 26.57$ & $40.87 \pm 11.94$ & $213.60 \pm 114.42$ & $81.80 \pm 41.03$ & $49.34 \pm 27.76$ \\
\hline & & 3 & $25.50 \pm 16.09$ & $12.81 \pm 5.15$ & $62.95 \pm 36.53$ & $33.86 \pm 20.77$ & $20.08 \pm 11.84$ \\
\hline & & 5 & $16.03 \pm 11.53$ & $4.18 \pm 1.54$ & $24.70 \pm 14.18$ & $15.63 \pm 11.69$ & $8.12 \pm 5.91$ \\
\hline & $\overline{\mathrm{TZ}}$ & 1 & $113.55 \pm 89.74$ & $45.05 \pm 14.43$ & $265.93 \pm 150.48$ & $59.85 \pm 30.26$ & $70.19 \pm 36.48$ \\
\hline & & 3 & $27.40 \pm 21.34$ & $12.67 \pm 5.68$ & $71.49 \pm 31.69$ & $26.53 \pm 16.10$ & $22.61 \pm 12.78$ \\
\hline & & 5 & $15.45 \pm 13.19$ & $4.88 \pm 3.04$ & $27.56 \pm 16.74$ & $16.16 \pm 13.03$ & $6.80 \pm 4.68$ \\
\hline \multirow[t]{6}{*}{ Effluent Ty } & G & 1 & $58.25 \pm 32.29$ & $51.64 \pm 15.26$ & $191.10 \pm 95.17$ & $73.71 \pm 38.16$ & $43.57 \pm 25.70$ \\
\hline & & 3 & $13.10 \pm 7.28$ & $16.57 \pm 6.85$ & $51.39 \pm 41.41$ & $30.22 \pm 12.42$ & $9.49 \pm 4.27$ \\
\hline & & 5 & $8.06 \pm 4.59$ & $6.15 \pm 2.87$ & $24.02 \pm 16.49$ & $11.53 \pm 7.18$ & $4.46 \pm 3.34$ \\
\hline & $\overline{\mathrm{TZ}}$ & 1 & $48.86 \pm 21.60$ & $46.40 \pm 9.94$ & $156.61 \pm 117.82$ & $51.35 \pm 20.73$ & $34.46 \pm 12.32$ \\
\hline & & 3 & $17.00 \pm 13.07$ & $15.87 \pm 13.40$ & $47.51 \pm 25.47$ & $31.00 \pm 34.31$ & $13.02 \pm 8.58$ \\
\hline & & 5 & $11.53 \pm 9.24$ & $7.67 \pm 6.44$ & $21.99 \pm 12.87$ & $9.18 \pm 5.91$ & $4.65 \pm 2.61$ \\
\hline \multirow[t]{6}{*}{ Effluent Cyp } & $\mathrm{G}$ & 1 & $97.72 \pm 38.37$ & $43.05 \pm 12.19$ & $201.85 \pm 123.02$ & $75.55 \pm 40.92$ & $85.56 \pm 37.72$ \\
\hline & & 3 & $21.68 \pm 7.62$ & $9.05 \pm 4.44$ & $67.62 \pm 44.51$ & $22.90 \pm 11.51$ & $20.83 \pm 10.56$ \\
\hline & & 5 & $12.31 \pm 6.83$ & $4.52 \pm 3.70$ & $26.45 \pm 13.02$ & $12.10 \pm 9.85$ & $7.97 \pm 3.72$ \\
\hline & $\mathrm{TZ}$ & 1 & $97.21 \pm 43.21$ & $31.76 \pm 7.88$ & $141.70 \pm 78.45$ & $68.37 \pm 56.88$ & $70.70 \pm 28.80$ \\
\hline & & 3 & $21.04 \pm 5.21$ & $7.52 \pm 4.22$ & $33.27 \pm 22.72$ & $16.85 \pm 8.68$ & $23.78 \pm 6.94$ \\
\hline & & 5 & $13.01 \pm 4.86$ & $7.81 \pm 8.46$ & $19.75 \pm 11.96$ & $21.69 \pm 28.87$ & $7.73 \pm 2.75$ \\
\hline \multirow[t]{6}{*}{ Effluent Unplanted } & $\mathrm{G}$ & 1 & $135.93 \pm 70.313$ & $50.58 \pm 13.99$ & $266.66 \pm 124.49$ & $124.16 \pm 84.13$ & $83.10 \pm 28.36$ \\
\hline & & 3 & $60.13 \pm 29.71$ & $14.41 \pm 5.33$ & $62.60 \pm 40.25$ & $37.23 \pm 19.72$ & $26.31 \pm 11.86$ \\
\hline & & 5 & $19.58 \pm 8.19$ & $15.22 \pm 18.06$ & $48.55 \pm 48.42$ & $29.06 \pm 30.72$ & $9.18 \pm 3.00$ \\
\hline & $\mathrm{TZ}$ & 1 & $130.30 \pm 81.01$ & $43.20 \pm 11.07$ & $208.67 \pm 166.63$ & $159.14 \pm 129.35$ & $77.06 \pm 55.54$ \\
\hline & & 3 & $42.49 \pm 15.75$ & $15.22 \pm 4.53$ & $45.91 \pm 44.49$ & $34.41 \pm 17.22$ & $23.81 \pm 8.95$ \\
\hline & & 5 & $24.42 \pm 11.89$ & $14.66 \pm 14.79$ & $35.07 \pm 25.16$ & $43.98 \pm 41.82$ & $10.98 \pm 5.54$ \\
\hline
\end{tabular}


International Journal of Applied Engineering Research ISSN 0973-4562 Volume 13, Number 22 (2018) pp. 15740-15748

(C) Research India Publications. https://dx.doi.org/10.37622/IJAER/13.22.2018.15740-15748

Table 3. Removal of AFs, ATZ, MDHJ, CAF and GAL as a function of treatment.

\begin{tabular}{|c|c|c|c|c|c|c|c|}
\hline Plant & PM & HRT & AFs & ATZ & MDHJ & CAF & GAL \\
\hline \multirow{6}{*}{$\mathrm{Phr}$} & \multirow{3}{*}{$\mathrm{G}$} & 1 & 75.74 & 44.49 & 53.62 & 94.43 & 71.22 \\
\hline & & 3 & 86.41 & 56.34 & 73.27 & 95.83 & 87.95 \\
\hline & & 5 & 88.28 & 89.75 & 85.88 & 96.75 & 92.08 \\
\hline & \multirow{3}{*}{$\mathrm{TZ}$} & 1 & 61.47 & 38.81 & 42.25 & 95.93 & 59.07 \\
\hline & & 3 & 85.40 & 56.81 & 69.64 & 96.73 & 86.43 \\
\hline & & 5 & 88.71 & 88.04 & 84.24 & 96.64 & 93.37 \\
\hline \multirow{6}{*}{ Ty } & \multirow{3}{*}{$\mathrm{G}$} & 1 & 61.05 & 95.29 & 76.15 & 81.44 & 34.15 \\
\hline & & 3 & 79.58 & 96.51 & 94.67 & 93.47 & 47.16 \\
\hline & & 5 & 88.11 & 97.92 & 96.23 & 94.90 & 86.95 \\
\hline & \multirow{3}{*}{$\mathrm{TZ}$} & 1 & 68.08 & 96.72 & 81.14 & 84.44 & 40.84 \\
\hline & & 3 & 81.12 & 96.42 & 92.69 & 91.52 & 49.39 \\
\hline & & 5 & 89.12 & 98.35 & 96.07 & 92.70 & 83.71 \\
\hline \multirow{6}{*}{ Cyp } & \multirow{3}{*}{$\mathrm{G}$} & 1 & 53.67 & 94.57 & 47.27 & 64.95 & 38.19 \\
\hline & & 3 & 70.28 & 97.08 & 87.06 & 88.04 & 68.05 \\
\hline & & 5 & 86.38 & 97.73 & 93.00 & 91.90 & 90.02 \\
\hline & \multirow{3}{*}{$\mathrm{TZ}$} & 1 & 67.48 & 95.08 & 56.43 & 65.14 & 54.40 \\
\hline & & 3 & 85.38 & 97.85 & 85.23 & 88.39 & 73.47 \\
\hline & & 5 & 89.83 & 95.94 & 93.20 & 91.43 & 82.75 \\
\hline \multirow{6}{*}{ Unplanted } & \multirow{3}{*}{$\mathrm{G}$} & 1 & 33.95 & 90.36 & 44.73 & 47.38 & 21.62 \\
\hline & & 3 & 65.06 & 93.97 & 79.25 & 57.87 & 35.45 \\
\hline & & 5 & 62.59 & 91.86 & 87.93 & 80.71 & 49.70 \\
\hline & \multirow{3}{*}{$\mathrm{TZ}$} & 1 & 48.31 & 87.65 & 48.75 & 49.56 & 33.06 \\
\hline & & 3 & 74.37 & 94.42 & 81.22 & 70.23 & 31.81 \\
\hline & & 5 & 72.97 & 87.68 & 85.56 & 75.95 & 51.56 \\
\hline
\end{tabular}

Table 4. $\mathrm{p}$ values of the influence of PM, Pl, HRT and their two-way interactions on the removal efficiency of AFs, ATZ, MDHJ, CAF and GAL (in bold $\mathrm{p}<0.05$ ).

\begin{tabular}{cccccc}
\hline & MDHJ & CAF & GAL & AFs & ATZ \\
\hline PM & $\mathbf{0 . 0 1 4 8}$ & 0.5260 & 0.9390 & 0.7899 & 0.3633 \\
\hline Pl & $\mathbf{0 . 0 0 0 4}$ & $\mathbf{0 . 0 0 0 1}$ & $\mathbf{0 . 0 0 1 4}$ & $\mathbf{0 . 0 0 0 3}$ & $\mathbf{0 . 0 0 0 1}$ \\
\hline HRT & $\mathbf{0 . 0 0 0 0}$ & $\mathbf{0 . 0 0 4 7}$ & $\mathbf{0 . 0 0 0 0}$ & $\mathbf{0 . 0 0 0 2}$ & $\mathbf{0 . 0 0 0 0}$ \\
\hline PM*Pl & $\mathbf{0 . 0 1 9 8}$ & 0.0917 & 0.5598 & 0.5193 & 0.6255 \\
\hline PM*HRT & 0.7366 & 0.1420 & 0.8433 & 0.5563 & 0.1948 \\
\hline Pl*HRT & 0.1092 & 0.0345 & 0.0508 & 0.1730 & $\mathbf{0 . 0 4 2 8}$ \\
\hline
\end{tabular}


International Journal of Applied Engineering Research ISSN 0973-4562 Volume 13, Number 22 (2018) pp. 15740-15748

(C) Research India Publications. https://dx.doi.org/10.37622/IJAER/13.22.2018.15740-15748

Table 5. Removal of AFs, ATZ, MDHJ, CAF and GAL reported by other studies. HSSF-CW: horizontal subsurface flow constructed wetland, SF-CW: Surface flow constructed wetland, VSF-CW: vertical subsurface flow constructed wetland

\begin{tabular}{|c|c|c|c|c|c|c|c|}
\hline \multirow[t]{2}{*}{ Type of water } & \multirow[t]{2}{*}{ Treatment system } & \multicolumn{5}{|c|}{ \%Removal/Compound } & \multirow[t]{2}{*}{ Author/Year } \\
\hline & & AFs & ATZ & MDHJ & CAF & GAL & \\
\hline Domestic wastewater & $\begin{array}{l}\text { On site Wetland } \\
\text { System }\end{array}$ & 58 & 54 & 99 & 93 & & Schaider/2017 [26] \\
\hline Domestic wastewater & HSSF-CW & & & & $82-90$ & 94 & Zhang/2012 [17] \\
\hline Domestic wastewater & SF-CW & & & $71-96$ & & $67-82$ & Reyes-Contreras/2012 [27] \\
\hline Domestic wastewater & Hybrid CW system & & & & $95-96$ & & $\mathrm{Li} / 2014[34]$ \\
\hline Domestic wastewater & VSF-CW & & & & 99 & & Matamoros/2007 [38] \\
\hline Municipal wastewater & SF-CW & $<8$ & & & & & Carranza-Díaz/2014 [39] \\
\hline Riverine water & SF-CW; HSSF-CW & $52 ; 61$ & & & & & Navarro/2011 [19] \\
\hline Riverine water & SF-CW & $76-90$ & & & & & Hiesh/2015 [20] \\
\hline Municipal wastewater & SF-CW & 98 & & & & & Sima and Holcova/2011 [40] \\
\hline Agricultural runoff & SF-CW & & $66-70$ & & & & Moore/2000 [24] \\
\hline Stormwater & SF-CW & & $50-60$ & & & & Page/2010 [25] \\
\hline Municipal wastewater & HSSF-CW & & $<25$ & & & & Matamoros/2007 [41] \\
\hline Nursery water & HSSF-CW & & $64-77$ & & & & Stearman/2003 [23] \\
\hline Aquaculture effluents & VSF-CW & & $87-100$ & & & & Gorito/2018 [22] \\
\hline Municipal wastewater & HSSF-CW & $0-90$ & & & & & Toro-Velez (2016) [42] \\
\hline Agricultural runoff & Grass Strips & & $0-10$ & & & & Vallee (2015) [43] \\
\hline Riverine water & SF-CW & & & 58 & & 51 & Matamoros/2017 [28] \\
\hline Riverine water & SF-CW & $94-96$ & & & & & Yang/2011 [21] \\
\hline Secondary effluent & SF-CW & $32-51$ & & & & & Dai/2017 [44] \\
\hline
\end{tabular}

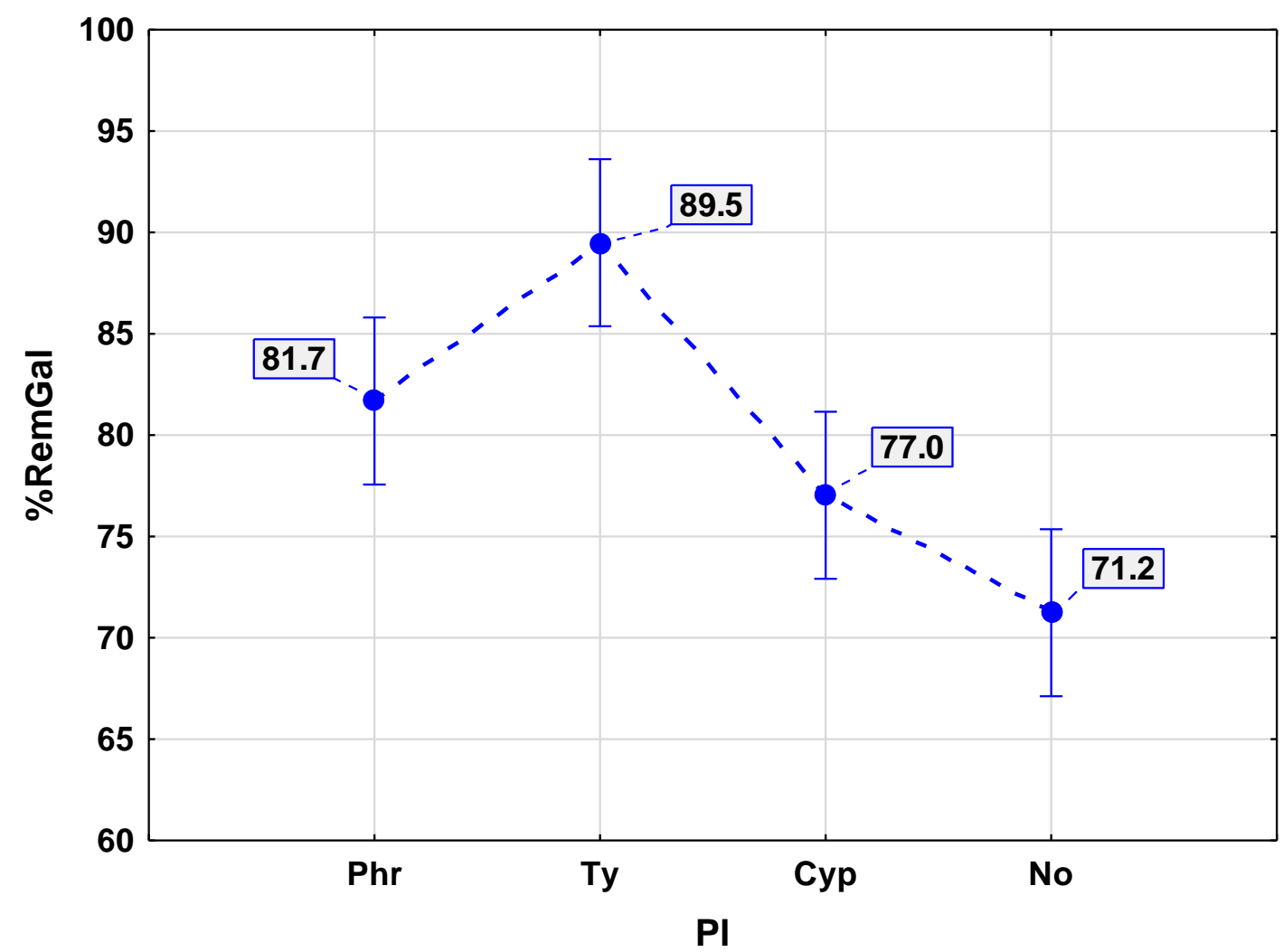

Figure 2. ANOVA mean values of GAL removal for the different plants (vertical bars denote 0.95 confidence intervals). 


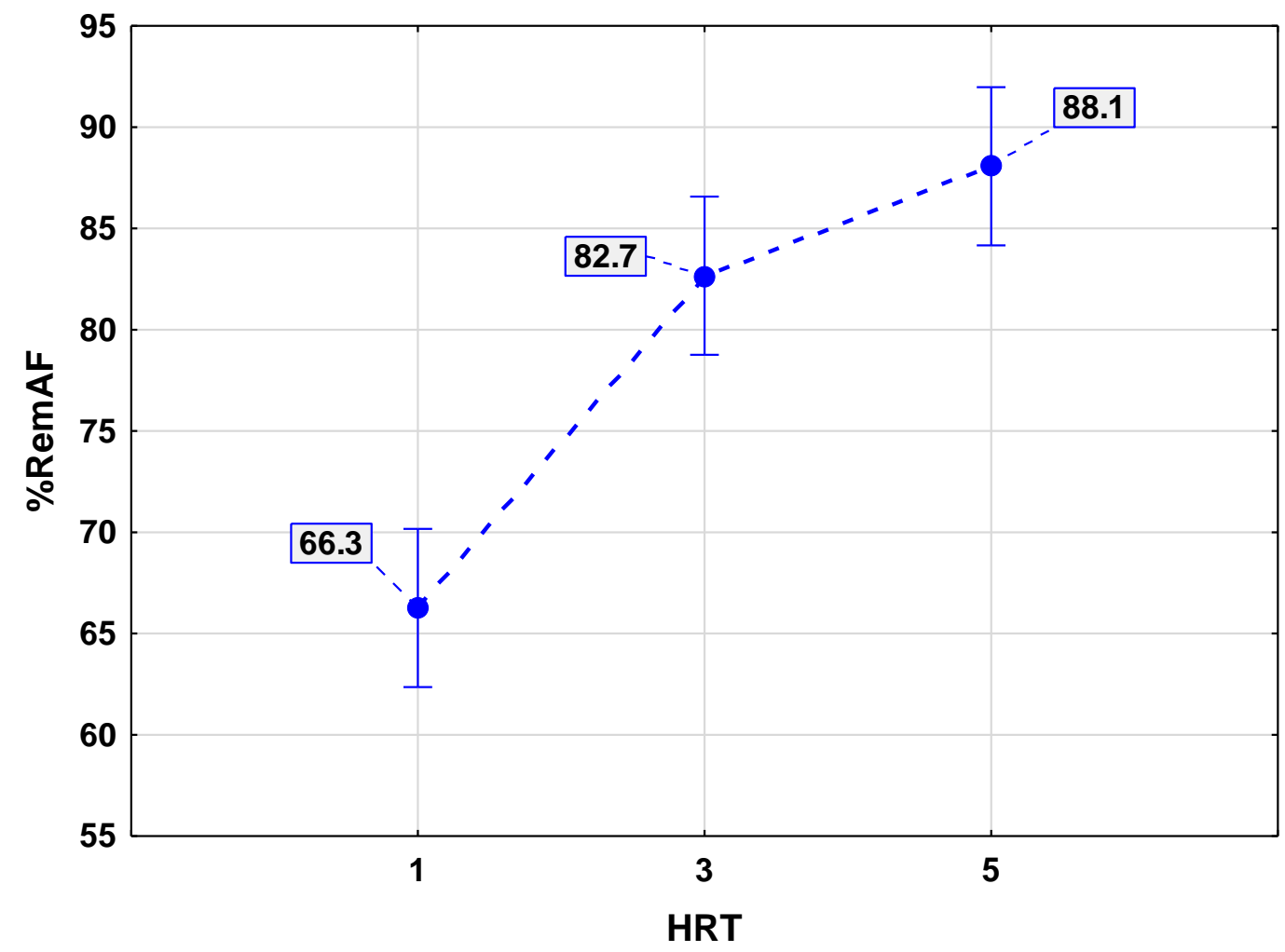

Figure 3. ANOVA mean values of AFs removal for the different HRT (vertical bars denote 0.95 confidence intervals).

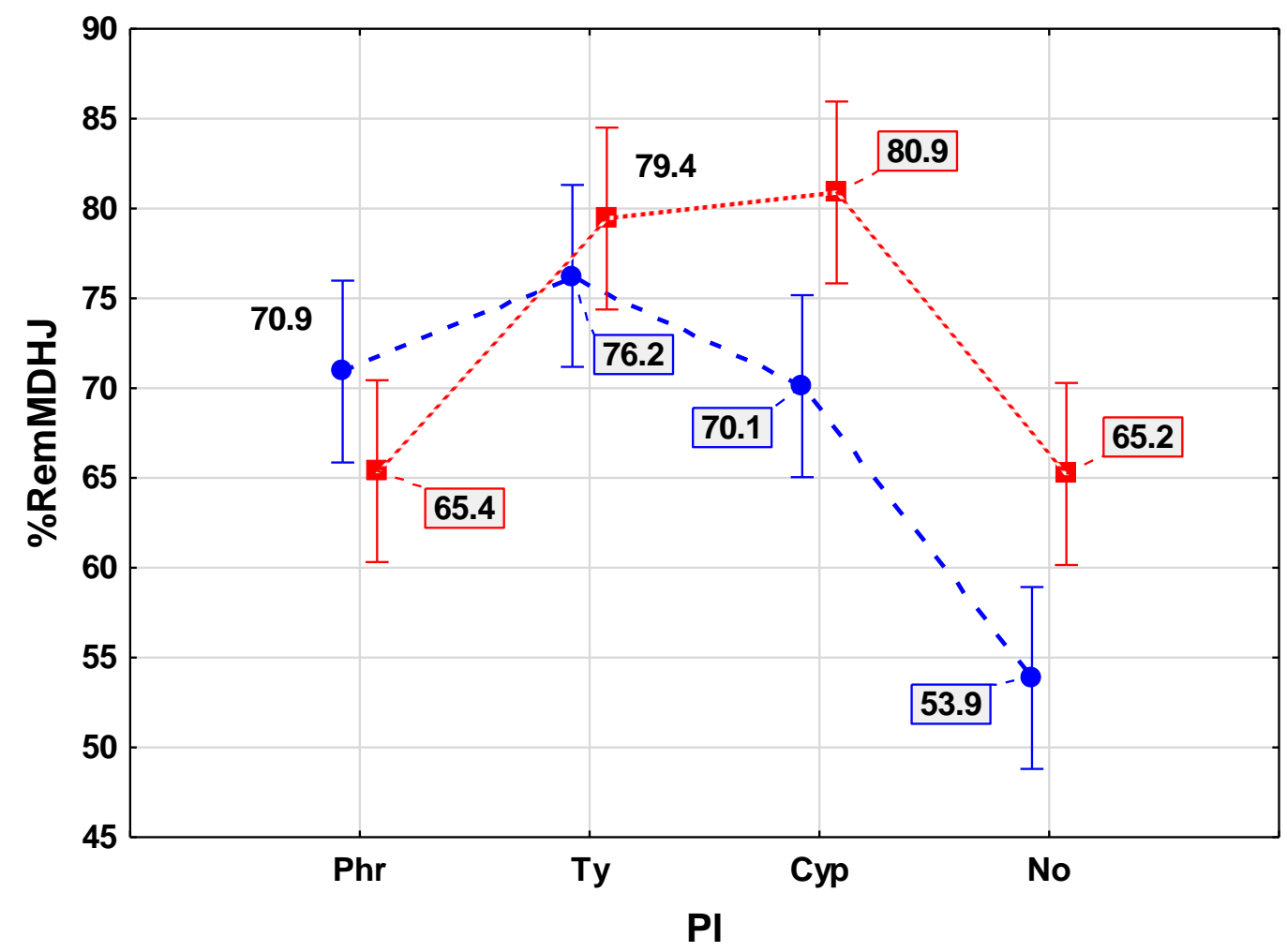

Figure 4. ANOVA mean values of MDHJ removal for the different plants and porous media (vertical bars denote 0.95 confidence intervals). 


\section{DISCUSSION}

The removal of AFs, ATZ, MDHJ, CAF, and GAL reported in other studies are presented in table 5. In the case of AFs results, it covers a wide range from 0 to $98 \%$, however, a different type of wastewater and wetlands treatment are shown therein. Removal in river water treatment with CWs [19-21], higher than 52\%, are similar to the results obtained in the present study. The ATZ is completely removed from aquaculture effluents in vertical flow constructed wetland [22], which is not the case for the horizontal subsurface flow constructed wetland and free surface wetland, was removal range around $50-70 \%$ [23-25], which are in concordance with the removal obtained in the present work. The MDHJ removals were in the range of those reported in the treatment of domestic wastewater with free surface wetland, around 70 - $98 \%$ [26-27] higher than in the treatment of river water, around $58 \%$ [28]. Meanwhile, the CAF is efficiently removed in all the CWs systems as shown in table 5 with removals higher than $87 \%$, these results are similar to those obtained in the present work. Finally, obtained GAL removals are lower than those reported for domestic wastewater treatment in wetland systems similar to the used in this work, around $97 \%$ [17], but are higher than those obtained in free surface wetlands, less than $82 \%$ [27].

The PM is an important component in CWs, particularly in horizontal sub-surface flow constructed wetlands. The substrate not only provides support for the growth of the plants and microorganisms biofilms but also interacts directly with pollutants through sorption processes. The sorption of pollutants on the PM surface implies different mechanisms, such as hydrophobic separations, van der Waals interactions, electrostatic interactions, ion exchange, and formation of surface complexes [12, 29-32]. The obtained results show that using TZ, which has a greater porosity than $G$, slightly gives better results, although the differences for most of the pollutants studied are not significant.

Plants in constructed wetlands play a significant role in the direct removal of many organic pollutants found in wastewaters. The diffusion process of OMPs in the tissues of the plant depends on the physicochemical characteristics of the compounds, including their hydrophobicity (according to what was expressed by the octanol/water partition coefficient logarithm $\log \mathrm{K}_{\mathrm{ow}}$ ), solubility in water and concentration [12] [33].

Plants in artificial wetlands play an additional important role in stimulating the development and activities of microbial populations that are supported by rhizodeposition products, which cause a number of diverse biological processes that occur in the rhizosphere [34]. The majority of the plant species in artificial wetlands are able to release oxygen around their root tips and in young laterals [33]. The oxygen released in the rhizosphere can also promote chemical oxidation processes of pollutants in wastewaters and favors the development of aerobic microorganisms in the rhizosphere, which induces more efficient biodegradation processes [12] [34]. The continuous release of oxygen in the root zone of plants could counteract the biological consumption of chemical oxygen in the rhizosphere. The use of several plant species in wastewater treatment wetlands has been reported; among them, the most popular are Phragmites australis, Typha angustifolia, and Typha latifolia. The results of the experiments reported in [35-36] indicate that $P$. australis exhibits a greater efficiency than $T$. angustifolia. However, in [37] it was observed the superiority of Typha spp. compared with $P$. australis due to the greater transpiration rates of Typha spp. Similarly, the results of this work show that in the systems planted with Ty greater removals are obtained, although in many cases the differences are not significant, especially with the removals obtained with Cyp.

\section{CONCLUSIONS}

Constructed wetlands are gaining increasingly greater interest due to their efficiency in eliminating OMPs, such as AFs, ATRZ, MDHJ, CAF, and GAL. The results of this study allow us to conclude that the removal of these emerging contaminants in horizontal sub-surface flow constructed wetlands is significantly influenced by the presence of plants and the hydraulic retention time. The good removals obtained with the treatment of one day allow concluding that it is possible to use these systems to treat polluted river water if streams are derived from the river and CWs batteries are used in series.

\section{Acknowledgments}

The authors thank the Spanish Agency of International Cooperation for Development and the Secretariat of Public Education of Mexico for the funding provided in Projects 11CAP2-1756 and PADES-2013-21011-051, respectively.

\section{REFERENCES}

[1] Sousa, J. C. G., Ribeiro, A. R., Barbosa, M. O., Ribeiro, C., Tiritan, M. E., Pereira, M. F. R., \& Silva, A. M. T. (2019). Monitoring of the 17 EU Watch List contaminants of emerging concern in the Ave and the Sousa Rivers. Science of The Total Environment. 649, 1083-1095.

[2] Schaider, L. A., Rodgers, K. M., \& Rudel, R. A. (2017). Review of Organic Wastewater Compound Concentrations and Removal in Onsite Wastewater Treatment Systems. Environmental Science \& Technology, 51(13), 7304-7317.

[3] Tijani, J. O., Fatoba, O. O., Babajide, O. O., \& Petrik, L. F. (2016). Pharmaceuticals, endocrine disruptors, personal care products, nanomaterials and perfluorinated pollutants: a review. Environmental Chemistry Letters, 14(1), 27-49.

[4] Gorito, A. M., Ribeiro, A. R., Almeida, C. M. R., \& Silva, A. M. T. (2017). A review on the application of constructed wetlands for the removal of priority substances and contaminants of emerging concern listed in recently launched EU legislation. Environmental Pollution, 227, 428-443. 
[5] Liu, J.-L., \& Wong, M.-H. (2013). Pharmaceuticals and personal care products (PPCPs): A review on environmental contamination in China. Environment International, 59, 208-224.

[6] Auvinen, H., Havran, I., Hubau, L., Vanseveren, L., Gebhardt, W., Linnemann, V., ... Rousseau, D. P. L. (2017). Removal of pharmaceuticals by a pilot aerated sub-surface flow constructed wetland treating municipal and hospital wastewater. Ecological Engineering, 100, 157-164.

[7] Zhang, X., Jing, R., Feng, X., Dai, Y., Tao, R., Vymazal, J., ... Yang, Y. (2018). Removal of acidic pharmaceuticals by small-scale constructed wetlands using different design configurations. Science of The Total Environment, 639, 640-647.

[8] Vymazal, J., Dvořáková Březinová, T., Koželuh, M., $\&$ Kule, L. (2017). Occurrence and removal of pharmaceuticals in four full-scale constructed wetlands in the Czech Republic - the first year of monitoring. Ecological Engineering, 98, 354-364.

[9] Kadlec, R. H., \& Wallace, S. D. (2009). Treatment Wetlands, Second Edition. Treatment Wetlands, Second Edition.

[10] Mitsch W, \& Gosselink J. (2007). Wetlands. 4th ed. Inc JW\&S, editor. Hoboken New Jersey: John Wiley $\&$ Sons

[11] Zhang, D., Gersberg, R. M., Ng, W. J., \& Tan, S. K. (2014). Removal of pharmaceuticals and personal care products in aquatic plant-based systems: A review. Environmental Pollution, 184, 620-639.

[12] Dordio, A.V., Carvalho, A.J., 2013. Organic xenobiotics removal in constructed wetlands, with emphasis on the importance of the support matrix. J. Hazard. Mater. 252-253, 272-292.

[13] Meng P, Pei H, Hu W, Shao Y, Li Z. (2014). How to increase microbial degradation in constructed wetlands: Influencing factors and improvement measures. Bioresource Technology, 157, 316-326.

[14] Zhang, X., Wang, H., He, L., Lu, K., Sarmah, A., Li, J., ... Huang, H. (2013). Using biochar for remediation of soils contaminated with heavy metals and organic pollutants. Environmental Science and Pollution Research, 20(12), 8472-8483.

[15] Navarro A, Herrera J, Caso L, Marrugo J. (2013). Calidad del agua del río Nexapa. In Ramos $\mathbf{M}$, Aguilera V, editors. Ciencias Naturales y Exactas Handbook. Guanajuato: ECORFAN; 2013. p. 83-97.

[16] Matamoros, V., \& Salvadó, V. (2012). Evaluation of the seasonal performance of a water reclamation pond-constructed wetland system for removing emerging contaminants. Chemosphere, 86(2), 111117.

[17] Zhang, D. Q., Gersberg, R. M., Hua, T., Zhu, J., Tuan, N. A., \& Tan, S. K. (2012). Pharmaceutical removal in tropical subsurface flow constructed wetlands at varying hydraulic loading rates. Chemosphere, 87(3), 273-277.

[18] Yeasmin F, Rahman S, Rana S, Fatema K, Hossain M. (2011). Determination of carcinogenic polycyclic aromatic hydrocarbons (pahs), anthracene in different variety of fish samples in the Bangsai river of Bangladesh. African Journal of Food, Agriculture, Nutrition and Development, 11(2), 4664-4672

[19] Navarro, A. E., Hernández, M. E., Bayona, J. M., Morales, L., \& Ruiz, P. (2011). Removal of selected organic pollutants and coliforms in pilot constructed wetlands in southeastern Mexico. International Journal of Environmental and Analytical Chemistry, 91(7-8), 680-692.

[20] Hsieh, C. Y., Liaw, E. T., \& Fan, K. M. (2015). Removal of veterinary antibiotics, alkylphenolic compounds, and estrogens from the Wuluo constructed wetland in southern Taiwan. Journal of Environmental Science and Health, Part A, 50(2), 151-160.

[21] Yang, L.N., Li, Z.Y., Zou, L., Gao, H.W., 2011. Removal capacity and pathways ofphenolic endocrine disruptors in an estuarine wetland of natural reed bed.Chemosphere 83, 233-239.

[22] Gorito, A. M., Ribeiro, A. R., Gomes, C. R., Almeida, C. M. R., \& Silva, A. M. T. (2018). Constructed wetland microcosms for the removal of organic micropollutants from freshwater aquaculture effluents. Science of The Total Environment, 644, 1171-1180.

[23] Stearman, G. K., George, D. B., Carlson, K., \& Lansford, S. (2003). Pesticide removal from container nursery runoff in constructed wetland cells.Journal of environmental quality, 32(4), 15481556.

[24] Moore, M. T., Rodgers Jr, J. H., Cooper, C. M., \& Smith Jr, S. (2000). Constructed wetlands for mitigation of atrazine-associated agricultural runoff. Environmental pollution, 110(3), 393-399

[25] Page, D., Dillon, P., Mueller, J., \& Bartkow, M. (2010). Quantification of herbicide removal in a constructed wetland using passive samplers and composite water quality monitoring. Chemosphere,81(3), 394-399.

[26] Schaider, L. A., Rodgers, K. M., \& Rudel, R. A. (2017). Review of Organic Wastewater Compound Concentrations and Removal in Onsite Wastewater Treatment Systems. Environmental Science \& Technology, 51(13), 7304-7317.

[27] Schaider, L. A., Rodgers, K. M., \& Rudel, R. A. (2017). Review of Organic Wastewater Compound Concentrations and Removal in Onsite Wastewater Treatment Systems. Environmental Science \& Technology, 51(13), 7304-7317. 
[28] Schaider, L. A., Rodgers, K. M., \& Rudel, R. A. (2017). Review of Organic Wastewater Compound Concentrations and Removal in Onsite Wastewater Treatment Systems. Environmental Science \& Technology, 51(13), 7304-7317.

[29] Haberl, R., Grego, S., Langergraber, G., Kadlec, R. H., Cicalini, A.-R., Dias, S. M., Hebner, A. (2003). Constructed wetlands for the treatment of organic pollutants. Journal of Soils and Sediments, 3(2), 109.

[30] Tolls J. (2001). Sorption of veterinary pharmaceuticals in soils: a review. Environ Sci Technol 2001;35:3397-406.

[31] Pei Z, Kong J, Shan XQ, Wen B. (2012). Sorption of aromatic hydrocarbons onto montmorillonite as affected by norfloxacin. J Hazard Mater, 203-204, $137-44$

[32] Reddy KR, DeLaune RD. Biogeochemistry of wetlands: science and applications. Boca Raton, FL: CRC Press; 2008.

[33] Wang, Q., Hu, Y., Xie, H., \& Yang, Z. (2018). Constructed Wetlands: A Review on the Role of Radial Oxygen Loss in the Rhizosphere by Macrophytes. Water, 10(6), 678.

[34] Li, Y., Zhu, G., Ng, W. J., \& Tan, S. K. (2014). A review on removing pharmaceutical contaminants from wastewater by constructed wetlands: Design, performance and mechanism. Science of The Total Environment, 468-469, 908-932.

[35] Hijosa-Valsero, M., Matamoros, V., SidrachCardona, R., Martín-Villacorta, J., Bécares, E., \& Bayona, J. M. (2010). Comprehensive assessment of the design configuration of constructed wetlands for the removal of pharmaceuticals and personal care products from urban wastewaters. Water Research, 44(12), 3669-3678.

[36] Hijosa-Valsero M, Matamoros V, Sidrach-Cardona R, Pedescoll A, Martín-Villacorta J, García J, Bayona JM, Bécares E. (2011). Influence of design, physico-chemical and environmental parameters on pharmaceuticals and fragrances removal by constructed wetlands. Water Sci Technol, 63(11), 2527-2534

[37] Dordio, A., Pinto, J., Barrocas Dias, C., Pinto, A. P., Palace Carvalho, A. J., \& Teixeira, D. M. (2009). Atenolol removal in microcosm constructed wetlands. International Journal of Environmental Analytical Chemistry, 89(8-12), 835-848.

[38] Matamoros V, Arias C, Brix H, Bayona JM. (2007). Removal of pharmaceuticals and personal care products (PPCPs) from urban wastewater in a pilot vertical flow constructed wetland and a sand filter.. Environ. Sci. Technol, 41(23), 8171-8177

[39] Carranza-Diaz, O., Schultze-Nobre, L., Moeder, M., Nivala, J., Kuschk, P., \& Koeser, H. (2014).
Removal of selected organic micropollutants in planted and unplanted pilot-scale horizontal flow constructed wetlands under conditions of high organic load.Ecological Engineering, 71, 234-245.

[40] Šíma, J., \& Holcová, V. (2011). Removal of nonionic surfactants from wastewater using a constructed wetland. Chemistry \& biodiversity, 8(10), 18191832.

[41] Matamoros, V., Puigagut, J., García, J., \& Bayona, J. M. (2007). Behavior of selected priority organic pollutants in horizontal subsurface flow constructed wetlands: a preliminary screening. Chemosphere, 69(9), 1374-1380.

[42] Schaider, L. A., Rodgers, K. M., \& Rudel, R. A. (2017). Review of Organic Wastewater Compound Concentrations and Removal in Onsite Wastewater Treatment Systems. Environmental Science \& Technology, 51(13), 7304-7317.

[43] Schaider, L. A., Rodgers, K. M., \& Rudel, R. A. (2017). Review of Organic Wastewater Compound Concentrations and Removal in Onsite Wastewater Treatment Systems. Environmental Science \& Technology, 51(13), 7304-7317.

[44] Dai, Y. N., Tao, R., Tai, Y. P., Tam, N. F. Y., Dan, A., \& Yang, Y. (2017). Application of a full-scale newly developed stacked constructed wetland and an assembled bio-filter for reducing phenolic endocrine disrupting chemicals from secondary effluent. Ecological Engineering, 99, 496-503. 